\title{
Effectiveness of protected areas for jaguars: the case of the Taiamã Ecological Station in Brazil
}

\author{
Henrique Matheus Cardoso ${ }^{1,3,5}$; Ronaldo Gonçalves Morato ${ }^{2,6}$; Selma Samiko Miyazaki ${ }^{3}{ }^{3}$; Thadeu Deluque Costa Pereira ${ }^{3,8}$; \\ Gediendson Ribeiro de Araújo, ${ }^{4,9}$ \& Daniel Luis Zanella Kantek, ${ }^{3,10}$
}

1 Universidade do Estado de Mato Grosso (UNEMAT). Cáceres, MT, Brasil.

${ }^{2}$ Instituto Chico Mendes de Conservação da Biodiversidade (ICMBIO), Centro Nacional de Pesquisa e Conservação de Mamíferos Carnívoros (CENAP). Atibaia, SP, Brasil.

${ }^{3}$ Instituto Chico Mendes de Conservação da Biodiversidade (ICMBIO), Estação Ecológica de Taiamã (EET). Cáceres, MT, Brasil.

${ }^{4}$ Universidade Federal de Viçosa (UFV), Departamento de Medicina Veterinária (DVT). Viçosa, MG, Brasil.

${ }^{5}$ ORCID: http://orcid.org/0000-0002-8530-9263. E-mail: henriquematheus70@gmail.com

${ }^{6}$ ORCID: http://orcid.org/0000-0002-8304-9779. E-mail: ronaldo.morato@icmbio.gov.br

7 ORCID: http://orcid.org/0000-0002-9815-1709. E-mail: selma.miyazaki@icmbio.gov.br

${ }^{8}$ ORCID: http://orcid.org/0000-0003-0718-1054. E-mail: thadeu.pereira@icmbio.gov.br

${ }^{9}$ ORCID: http://orcid.org/0000-0002-6460-946X. E-mail: gediendson@gmail.com

${ }^{10}$ ORCID: http://orcid.org/0000-0001-9558-1503. E-mail: daniel.kantek@icmbio.gov.br (corresponding author)

\begin{abstract}
The largest feline in the Americas and the third largest in the world, the jaguar is an apex predator in the food chain and a key species in the ecosystems where it occurs, developing important ecological functions in maintaining ecosystem balance. In Brazil, the Pantanal is considered an important refuge for the species, and protected areas such as the Taiamã Ecological Station (TES) are relevant for conservation of pristine ecosystem where the species persist. Thus, considering that this area is located in one of the regions with the highest concentration of this large cat in the Pantanal, the objective of this study was to evaluate the effectiveness of the protection given by the TES for the jaguar population. The station is a flooded island in the middle of the Paraguay river and surrounded by extensive wetlands. We monitored ten jaguars using GPS collar at the TES and its surroundings. The samples were separated into high-water season (January to June) and low-water season (July to December), and the estimated home ranges were grouped as: 1) residents only and 2) all monitored individuals. The stabilization of the home ranges of eight jaguars, considered residents, was determined through variograms. When all jaguars were analysed together there was $55 \%$ overlap between the clustered areas of the two analysed seasons. In the analysis excluding non-resident individuals there was $72 \%$ overlap between the clustered areas. The type of land cover inside these areas was very similar between these periods. The range of this protected area is not sufficient to effectively protect these jaguar populations, since the grouped home ranges of the resident animals studied are 3.5(wet)/2.5(dry) times larger than the area of the TES. However, the surroundings of the TES have low human impact and no deforestation and, in this way, the landscape context of the station may have a significant effect on the persistence of a large carnivore like the jaguar. However, it is necessary to create more protected areas in order to prevent possible future environmental changes in the areas surrounding TES.
\end{abstract}

Key-Words. Pantanal wetland; Panthera onca; Protected area; GPS-collar; Home range size.

\section{INTRODUCTION}

Jaguars (Panthera onca, Linnaeus 1785), the only neotropical representative of the subfamily Pantheridae, is the largest wild cat in the Americas and the third largest in the world (Seymour, 1989; Silver et al., 2004). As the apex predator of the food chain and key species in the ecosystems where it occurs, the species has important ecological functions in the maintenance of the ecosystem balance (Terborgh, 1990). In Brazil, the Amazon and the Pantanal are considered im- portant jaguar refuges (Sanderson et al., 2002). The Pantanal wetlands $\left(150,355 \mathrm{~km}^{2}\right)$ is located in the Upper Paraguay River Basin, in the centre of South America, covering neighbouring areas in Brazil, Bolivia and Paraguay, with roughly $80 \%$ of this area in the Brazilian side. This ecosystem has a high concentration and abundance of wildlife, and the annual flood pulse is the main determinant of ecological processes and patterns in the Pantanal (Harris et al., 2005; Alho, 2008; Tomas et al., 2019). In this biome, the jaguar occupies about $47 \%$ of the territory, with an effective pop- 
ulation size smaller than 1,000 individuals (Morato et al., 2013). Hunting for retaliation, prevention and sport, as well as the loss of habitat associated with agricultural expansion, are the main threats to the population in this region (Morato et al., 2013). The species is categorized as vulnerable (VU) in Brazil (ICMBio, 2018) and near threatened (NT) by the IUCN (Quigley et al., 2017).

There is wide variation in home range used by jaguars, which varies according to the type of environment, the availability of prey, seasonality, the rainfall regime and differences associated with sex (Schaller \& Crawshaw-Jr., 1980; Crawshaw-Jr. \& Quigley, 1991; Cavalcanti \& Gese, 2009; Cullen-Jr. et al., 2013; Morato et al., 2018a).

In the Pantanal, the largest populations of $P$. onca are found in the central-northern region, where the Taiamã Ecological Station (TES) is located, as well as in the southern portion of the floodplain (Quigley \& Crawshaw-Jr., 1992). These regions are considered extremely important for the long-term conservation of this large feline (Quigley \& Crawshaw, 1992). Besides being relevant for jaguar conservation, TES has been also considered as important for the maintenance of local fish stocks (Muniz et al., 2016; ICMBio, 2017) and bird diversity (Frota et al., 2020).

Protected areas (PAs) that have small populations of large carnivores are vulnerable to extinction through stochastic processes because of their naturally large home range and low densities (Nowell \& Jackson, 1996; Woodroffe \& Ginsberg, 1998). Additionally, in small to medium-sized PAs an important part of the large carnivores' range is at the periphery or outside these areas, and thus, the mortality outside negatively affects the population dynamics inside PAs (Inskip \& Zimmerman, 2009). In this context, it is known that the success of conservation measures of many species and communities that inhabit protected areas but constantly cross the administrative limits is highly influenced by the areas outside these protected spaces (Woodroffe \& Ginsberg, 1998; Ogada et al., 2003; Baskett et al., 2007). In this way the main objective of our study is an evaluation of the TES effectiveness in protecting jaguar inside and around its limits.

\section{MATERIAL AND METHODS}

The TES is a federal protected area $\left(16^{\circ} 48^{\prime} \mathrm{S}-16^{\circ} 58^{\prime} \mathrm{S}\right.$, $57^{\circ} 24^{\prime} \mathrm{W}-57^{\circ} 40^{\prime} \mathrm{W}$ ) between the Paraguay and Bracinho rivers and is located in the northern Pantanal, Cáceres municipality, Mato Grosso state of Brazil, and comprehends $115.55 \mathrm{~km}^{2}$. The Pantanal is one of the largest freshwater wetlands in the world (Harris et al., 2005; Junk \& Cunha, 2005; Tomas et al., 2019), harbouring a great diversity of aquatic environments influenced by the the flooding pulse (Junk \& Silva, 1999; Oliveira \& Calheiros, 2000). This protected area is mainly composed of floodplains, and its interior contains a great variety of aquatic environments, such as permanent, temporary lagoons, meander lagoons and 'corixos' (natural connections between rivers and lagoons that have great importance to water bodies in the Pantanal). The TES has high levels of biodiversity, high rates of fishing productivity and the occurrence of populations of vulnerable or endangered species (ICMBio, 2017).

The Station is characterized by different functional units. These are Aquatic-Terrestrial Transition Zones, swamps, and permanently aquatic areas. Among the main macrohabitats are the Purple Coraltree Monospecific Forest (forest dominated by Erythrina fusca Lour., which is locally known as "abobral"), Shrubland, Pioneer Polyspecific Forest which is present of the river margins, Flooded Grasslands composed of herbaceous plants, aquatic macrophytes, and floating islands and meadows (locally known as "campos de batumes", composed of plants and layers of organic matter accumulated by hydrological changes), lakes, and river channels (Frota et al., 2017). The buffer zone is characterized by irregular depression lakes, some of which are interconnected by floodplain channels (Wantzen et al., 2005), flooded grasslands, aquatic macrophytes, "abobral", and "campos de batumes". The Station was declared a Ramsar site in 2018.

The TES is inserted in a region that plays important roles in flood control and sediment depositional processes of the north Pantanal. This region is characterized by the overflow of waters in the Paraguay River and it is flooded during most of the year (Assine \& Silva, 2009).

In the vicinity of the TES, an environmental regulation (Resolution 02/2018 of the State Fisheries Council of the State of Mato Grosso, Brazil) delimits an area where fishing is prohibited (Fig. 1) to protect the fish fauna present in this region. Around the Station there is a private reserve, RPPN Jubran, with an area of $355,31 \mathrm{~km}^{2}$.

The period between January and June are the 6 months with the highest water level in the TES region, and at this time the plain beside a river channel is inundated. The other months (between July and December) are characterized by lower water levels (Santana et al., 2013).

Ten jaguars (six males and four females) were monitored using GPS collars in the TES between October 2013 and April 2016 under license from the Instituto Chico Mendes de Conservação da Biodiversidade (SISBIO number 30896-3). All data used to develop this study are available to the scientific community (Morato et al., 2018b).

The animals were captured according to the foot snare method (Balme et al., 2009), immobilized with a combination of tiletamine and zolazepam (Zoletil $100^{\circledR}$, Virbac SA, Carros-Cedex, France) and fitted with GPSsatellite collars (Lotek-Iridium).

These collars were programmed to obtain locations every hour. The drop-off system was programmed for 400 days, and when triggered, the transmitter collar automatically loosened from the animal. The collars were programmed to send data to the Iridium satellite system every 24 hours.

The location coordinates were separated into a 6-month wet period and a 6-month dry period. This separation into only two seasons occurred because the animal data did not show location points in all months of 


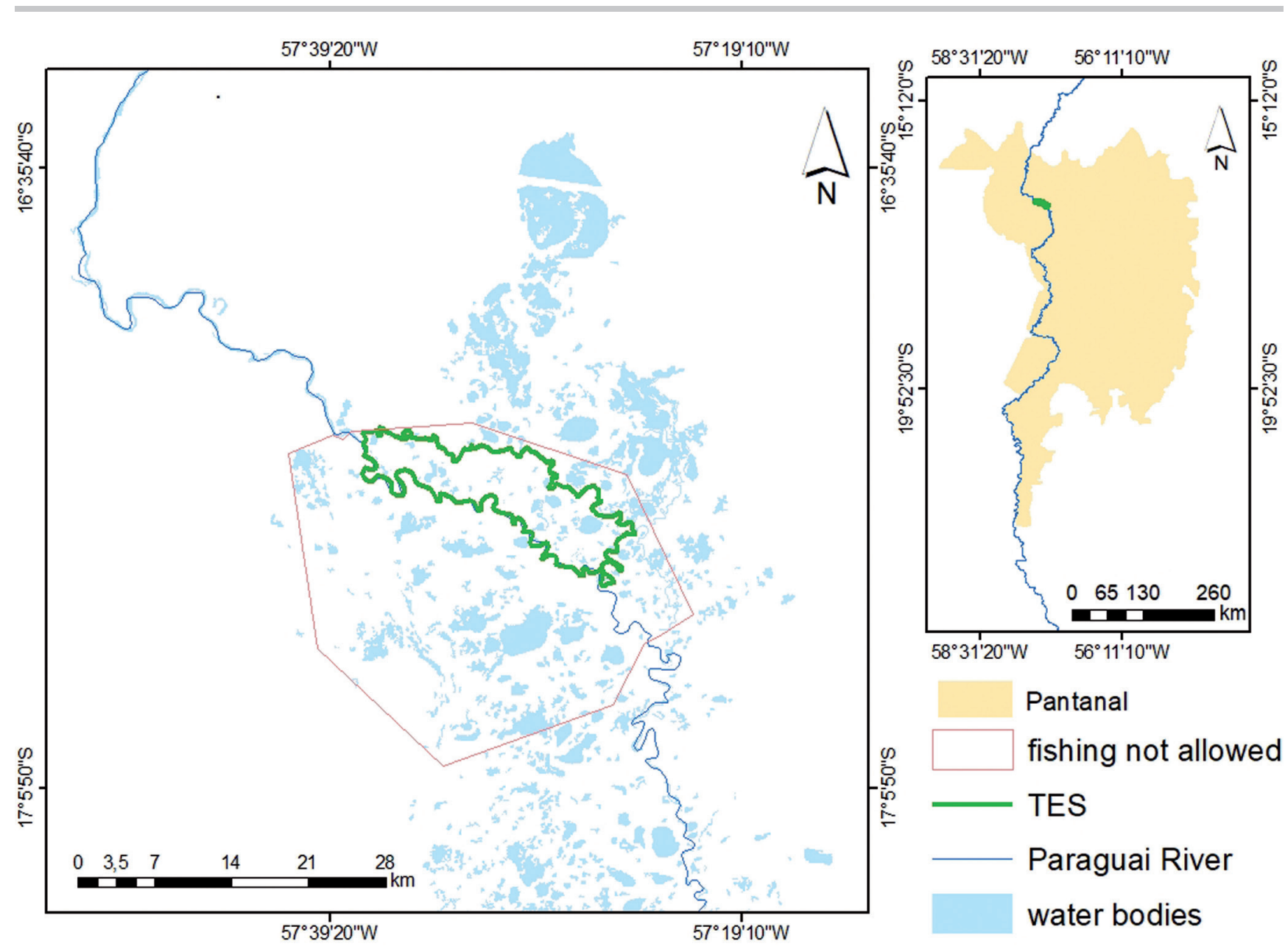

Figure 1. Pantanal Biome and the location in the flooded region of the Taiamã Ecological Station, Cáceres, Mato Grosso, Brazil.

the year. We gathered 42,126 individual locations from our sample of 10 jaguars.

In order to estimate the home range of the monitored animals, the Autocorrelational Kernel Density Estimation (AKDE) methodology was used through the software RStudio v1.0.143 with the Continuous-Time Movement Modeling (CTMM) package (Calabrese et al., 2016), which generates the probability of occurrence density based on parameters of the individual's own movement (for example, the time spent to reach the most extreme areas of their distribution), in addition to the basic parameters of Kernel Density Estimation. To generate home ranges in different seasonal periods, the location data for each animal were analysed separately in Rstudio to obtain shapefiles with information on occupation of the area during the wet and dry periods. Each shapefile resulted in home ranges with three confidence intervals, but only the mean maximum contour range/interval where the animal spent $95 \%$ of its time was considered for analysis.

One of the functions of the CTMM package (variogram) allowed us to verify the stabilization of the home ranges through variograms, and the stabilization of animal movement is represented by an asymptote, which is used to classify the animal as a resident. The variograms of non-resident animals, which do not yet have a fixed living area, do not reach the asymptote. These analyses were performed to correct possible distortions observed during the process of constructing comparative maps between the different periods, since the data on animals that do not yet have defined home ranges can generate different results from the observed patterns for resident individuals.

To verify if it would be possible to compare home ranges between dry and wet periods, the number of points in each period were obtained as a proportion of the total points for each individual. This analysis was performed for all individuals. The Kolmogorov-Smirnov test was performed to verify the normality of the data distribution in both periods. The $t$-test of one sample for the wet and dry periods was carried out separately using GraphPad Instat software version 3.0 to verify if the mean of the proportion of points per period (dry and wet) differed from $50 \%$.

In order to compare the different seasonal periods (low-water season and high water-season), the areas of use of all animals were grouped using the union tool in the Quantum Gis 3.0 program.

The $t$-test to compare difference between means (individual home ranges in $\mathrm{km}^{2}$ - without non-residents and M4) for the wet and dry periods was carried out separately using GraphPad Instat software version 3.0. The individual M4 was not included in this analysis because it was monitored only in the wet period.

The land cover classes were obtained through the MapBiomas Project (Brazilian Annual Land Use and Land Cover Mapping Project) (Projeto MapBiomas, 2020). 


\section{RESULTS}

The animals that provided the greatest amount of data were individual M1, monitored for 20 months and individual F2, monitored for 14 months.

The distribution of coordinate ratios between dry and wet periods was considered normal for the dry $(p=0.15)$ and wet $(p=0.18)$ periods. The means of the proportion of sampling points for each animal in each period were not significantly different from 50\% (dry: $p=0.1599$ and wet: $p=0.1435$ ).

The stabilization of the home ranges of eight jaguars, considered residents, was determined through variograms. In two animals (M1 and F3), the asymptote was not observed, and these two individuals were considered non-resident (Fig. 2). The latter were the individuals with the highest estimated areas of use, $514.33 \mathrm{~km}^{2}$ and $483.90 \mathrm{~km}^{2}$, respectively (Table 1 ).

The averages of the individual home ranges in the two periods did not differ statistically $(p=0.1825)$.
When grouping the home ranges of all jaguars observed in the high-water season and low-water season, $868.35 \mathrm{~km}^{2}$ and $393.54 \mathrm{~km}^{2}$ were obtained, respectively. When the non-resident individuals were removed from the grouping, the area in the wet was $375.97 \mathrm{~km}^{2}$ and that in the dry was $278.79 \mathrm{~km}^{2}$ (Figs. 3, 4).

When all jaguars were analysed together, there was overlap between the clustered areas of the two analysed seasons, with $55 \%$ of the area occupied during the wet season being used in the dry season and the other $45 \%$ not being used in the dry season. There was no change in the type of land cover inside clustered areas between seasons (Pearson's coefficient $=0.9984$ ), and the classes with the highest proportions observed were Natural Non-Forest Wet Area (57.20\% for dry and 58.13\% for wet), formation forest (33.86\% for dry and $31.26 \%$ for wet) and water bodies $(7.15 \%$ and $7.26 \%$, respectively). The other types of soil cover present in the clustered areas were savanna formation, countryside formation and pasture, all with very low proportions $(<1.3 \%)$.

Table 1. Home ranges of 10 monitored jaguars (Panthera onca) at the Taiamã Ecological Station, Mato Grosso, Brazil, from 0ctober 2013 to April 2016.

\begin{tabular}{|c|c|c|c|c|}
\hline \multirow{2}{*}{ ID } & \multicolumn{3}{|c|}{ Home Range size ( $\mathrm{km}^{2}$ ) } & \multirow{2}{*}{ Sampling period (months } \\
\hline & Whole period & Dry & Wet & \\
\hline M1 & 514.327 & 336.527 & 582.499 & $10 / 2013$ to $05 / 2015(20)$ \\
\hline M2 & 106.773 & 106.560 & 78.406 & $09 / 2014$ to $05 / 2015(09)$ \\
\hline M3 & 119.661 & 83.344 & 122.117 & $11 / 2014$ to $04 / 2015(06)$ \\
\hline M4 & 34.063 & 34.063 & & $09 / 2014(01)$ \\
\hline M5 & 51.594 & 100.634 & 32.898 & $12 / 2014$ to $08 / 2015$ (09) \\
\hline M6 & 206.900 & 117.774 & 308.779 & $10 / 2015$ to $04 / 2016(07)$ \\
\hline F1 & 74.112 & 89.488 & 32.723 & $10 / 2013$ to $04 / 2014(07)$ \\
\hline F2 & 43.507 & 61.624 & 19.756 & $10 / 2014$ to $12 / 2015(15)$ \\
\hline F3 & 483.896 & 38.368 & 501.27 & $12 / 2014$ to $04 / 2015(05)$ \\
\hline F4 & 44.764 & 48.006 & 36.555 & $10 / 2015$ to $02 / 2016(04)$ \\
\hline average ( $\pm \mathrm{SE}$ ) & $167.960 \pm 57.573$ & $89.873 \pm 29.373$ & $190.556 \pm 73.035$ & \\
\hline average whitout non-residents ( \pm SE) & $85.172 \pm 20.574$ & $65.480 \pm 12.955$ & $90.176 \pm 34.083$ & \\
\hline average without non-residents and M4 ( \pm SE) & $97.473 \pm 22.211$ & $69.968 \pm 14.033$ & $91.561 \pm 38.841$ & \\
\hline
\end{tabular}

A

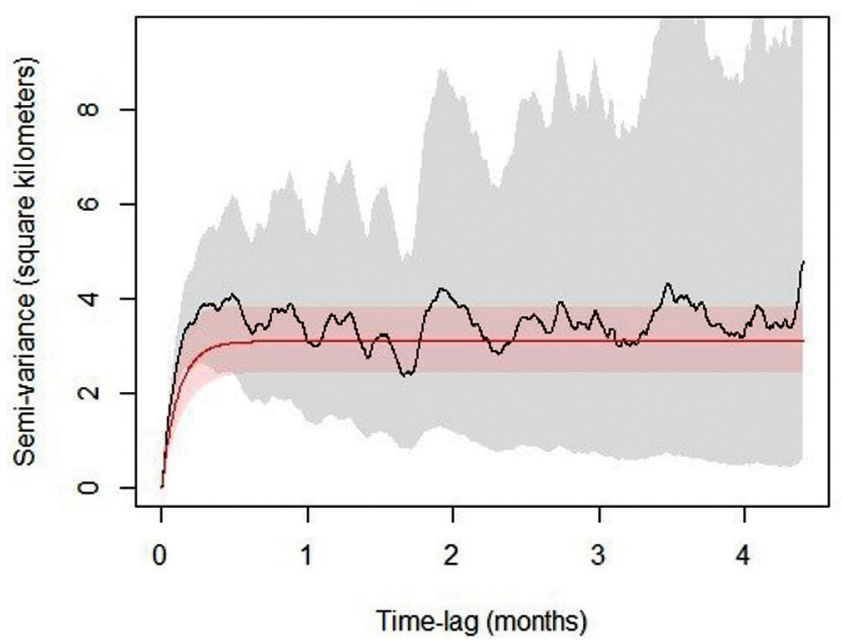

B

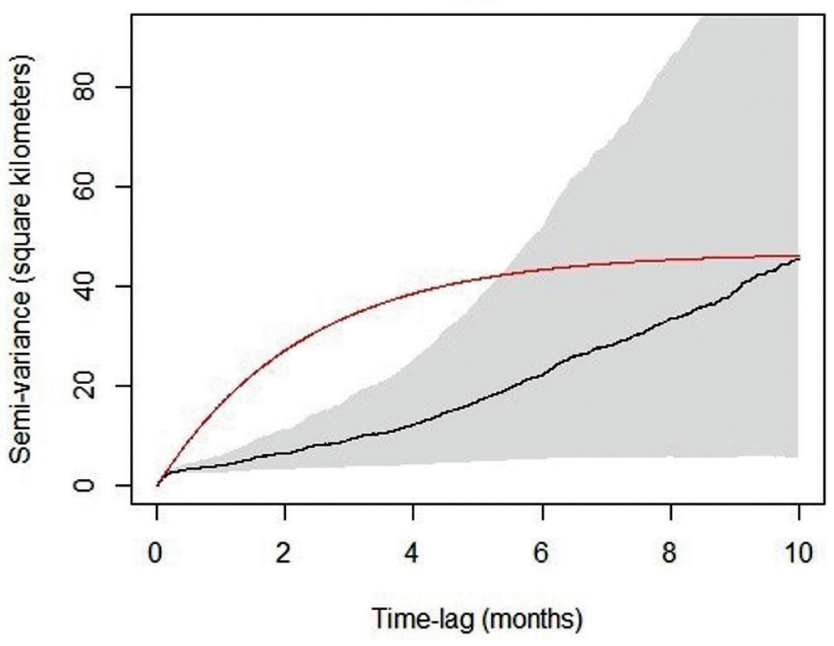

Figure 2. Variogram of the resident (A) and non-residents jaguars (B) at the Taiamã Ecological Station, Cáceres, Mato Grosso, Brazil, monitored by GPS collar from October 2013 to April 2016. The red line represents the fitted model, and the red shading represents the $95 \%$ Cl. (B) The non-resident jaguar M1. Note the lack of a clear asymptote despite the fact that the animal was monitored for a long period (591 days). This lack of asymptote indicates that this animal is not a range resident. For both $A$ and $B$, the fraction of the variogram displayed is $65 \%$ of the duration of each dataset. 


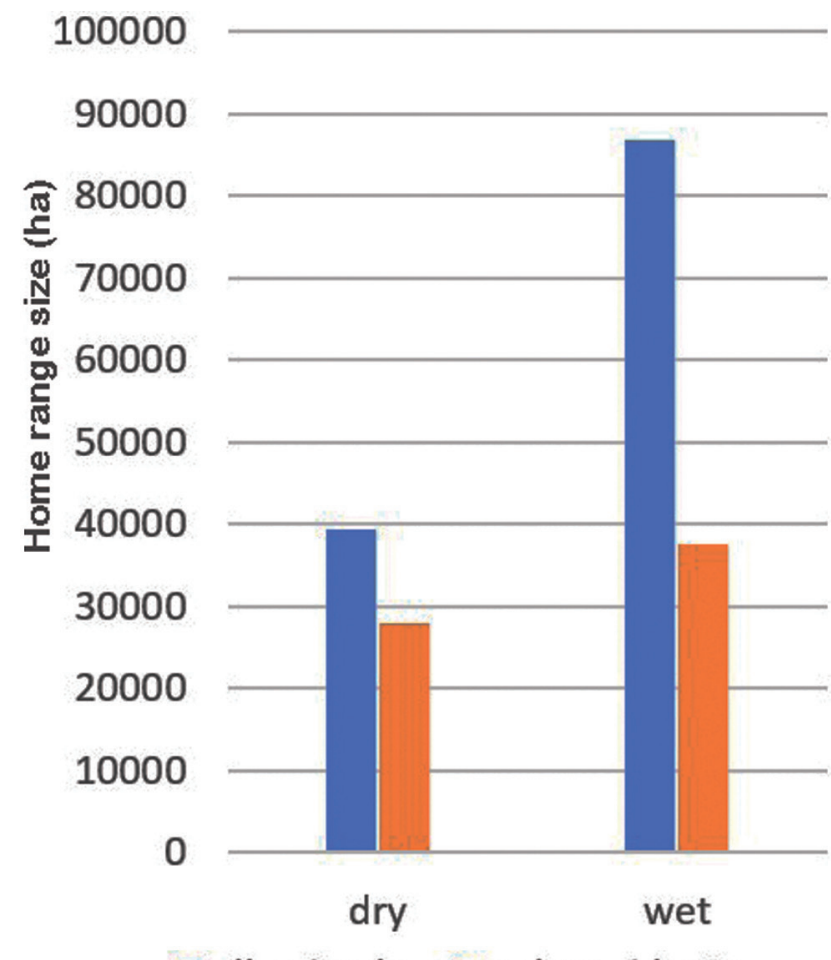

all animals $\square$ only residents

Figure 3. Grouped home ranges of the jaguars at the Taiamã Ecological Station, Cáceres, Mato Grosso, Brazil, monitored by GPS collar from 0ctober 2013 to April 2016.

A $57^{\circ} 36^{\prime} 0.0^{\prime \prime} \mathrm{W}$ $57^{\circ} 24^{\prime} 0.0^{\prime \prime} \mathrm{W}$

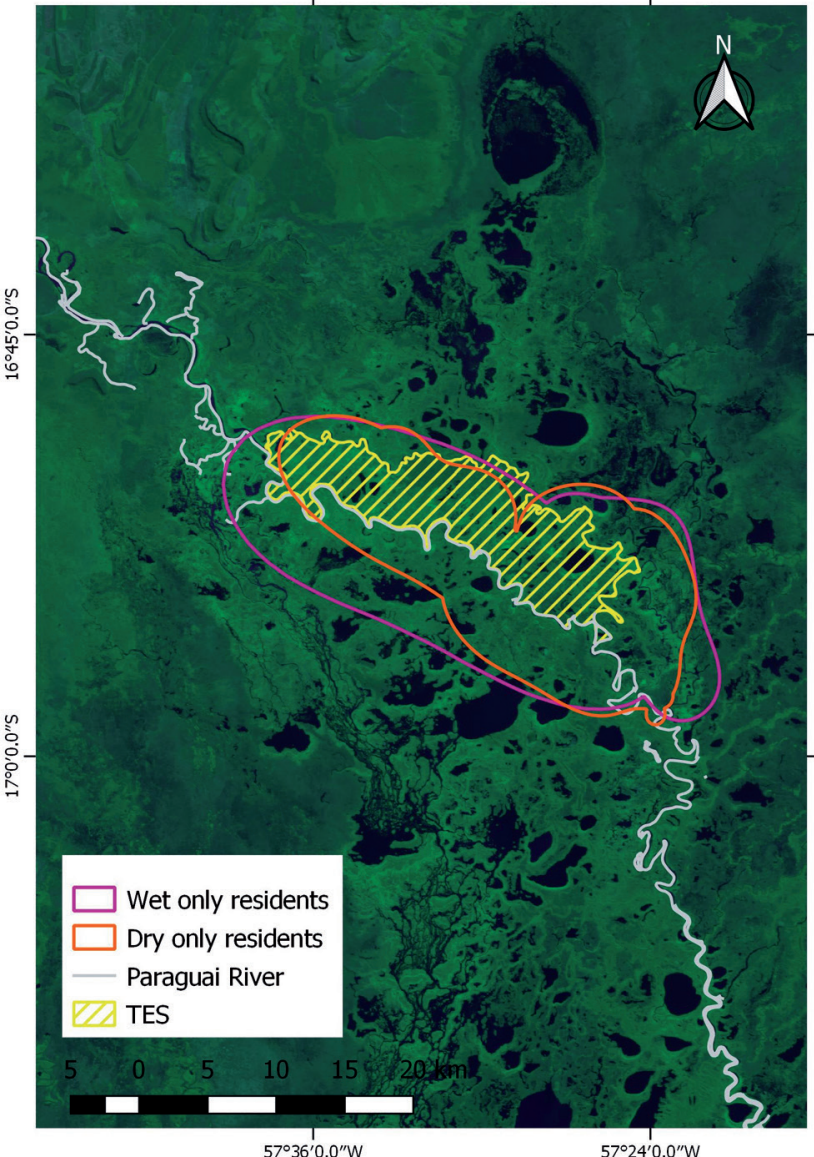

In the analysis excluding non-resident individuals (M1 and F3), 72\% of the area occupied during the wet period was used by the jaguars during the dry season. There was no change in the type of ground cover inside clustered areas between seasons (Pearson's coefficient $=0.9937)$, and the classes with the highest proportions observed were Natural Non-Forest Wet Area $(60.45 \%$ for dry and $60.05 \%$ for wet), formation forest $(33.85 \%$ for dry and $28.67 \%$ for wet) and water bodies (3.94\% and $5.25 \%$, respectively). The other types of soil cover present in the clustered areas were savanna formation, countryside formation and pasture, all with very low proportions $(<1.5 \%)$.

Moreover, when all jaguars were considered, only $0.45 \%$ of the dry season area did not overlap with the wet season, and when non-resident animals were removed, this value was $1.73 \%$.

The clustered areas used by jaguars, at any time, with all animals or without non-resident animals, is directly related to the Paraguay River, since the polygons follows the course of the river (Fig. 4).

\section{DISCUSSION}

The proportion of coordinates per individual in each season was not significantly different from $50 \%$, indi-

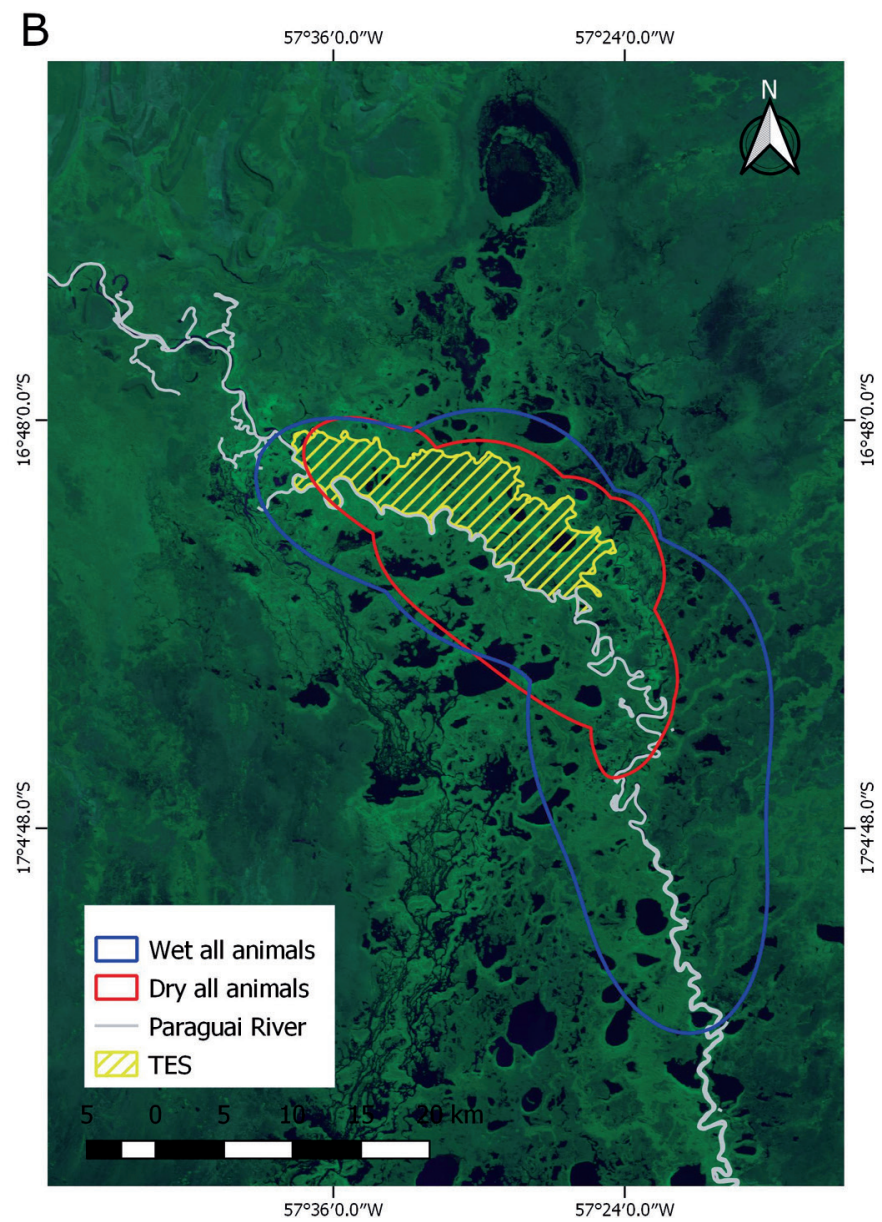

Figure 4. Grouped home ranges of resident jaguars (A) and all animals (B) during the high water-season (July to December - wet) and low-water season (January to June - dry) at the Taiamã Ecological Station and surroundings, Cáceres, Mato Grosso, Brazil, monitored by GPS collar from October 2013 to April 2016. 
cating the suitability of the data for comparison of the two seasons. Jaguars are solitary animals and are considered residents when they define their home range and non-residents when they do not define a home range (Schaller \& Crawshaw-Jr., 1980). We chose to analyse the overlap of clustered home ranges with and without the non-resident animals, since migrant individuals tend to increase their areas of use significantly, which would alter the results making comparisons difficult. Thus, in the analysis without the non-resident animals, individuals M1 and F3 were not used because they were considered non-resident animals during the sampling period. The jaguars considered resident in this study are mostly adult animals and have concentrated their home ranges in the TES and adjacent areas. The non-resident individuals were also identified at the time of capture as adults (4 years of age) (Morato et al., 2016) but with little life experience, as jaguars up to 13 years of age have been observed in the wild (Brown \& Lopez-Gonzales, 2001). The dispersal of M1 and F3 was possibly related to the age of these jaguars. Environmental dispersal of animals is defined as migration from their place of birth in response to conditions of overcrowding, selection of partners, territoriality, lack of adequate homes or parental expulsion (Howard, 1960). In addition, migration of young mammals avoids inbreeding (Dingle \& Drake, 2007). Dispersion of other felines such as Puma concolor (Morrison et al., 2015) and Panthera tigris (Gour et al., 2013) were also reported in the literature. Unlike $M 3$, which did not migrate in a specific direction, the F3 female migrated to the TSE southward along the Paraguay River, using a region of the Pantanal that is still very conserved and considered an ecological corridor (Silveira et al., 2014).

Jaguars' home range data from wet and dry seasons in the southern Pantanal revealed that the largest areas were occupied during the dry season, with a reduction in the area occupied in the wet period. This is due, according to the authors, to the isolation and concentration of prey on dry islands, resulting in a smaller displacement to capture animals with terrestrial habits, such as cattle, which correspond to $31.7 \%$ of the jaguar diet and are the main food item for this population. The increase in the home range of jaguars in the dry period is related to the dispersal of prey (Cavalcanti et al., 2012). The jaguars from the TES behave differently, in the grouped analysis they used a small estimated area in the dry period and increased the area used in the wet period (Fig. 4). However, when individual home ranges were compared, no statistical difference was observed. The different results observed between the two studies were possibly due to differences in the diet of these two populations and the type of environment they use. The area studied in the Southern Pantanal is less flooded than the TES region, and the jaguars analysed in our study feed mainly on aquatic prey (C. Eriksson, pers. comm., September 2018). In addition, there are no livestock in our study area. These differences in the behaviour of jaguars, both between environments and between time of the year, reflect the opportunistic nature of the species, which seems to take advantage of constantly changing environments and the variation of food resources in time and space (Emmons, 1987; Cavalcanti \& Gese, 2009; Morato et al., 2018a). More than 85 species of prey (wild and livestock/domestic), including mammals, reptiles and birds, were recorded in their diet throughout their geographical distribution (Seymour, 1989).

A study carried out about macrohabitats at the TES stipulated that during the period when the level of the Paraguay river is low, $48 \%$ of the area is composed of marshland (batume), $47 \%$ is transitional aquatic and terrestrial areas with a predominance of terrestrial areas (flooded fields) and 5\% is permanent aquatic areas, indicating that in the flood season almost the entire station and its surroundings are flooded (Frota et al., 2017). In addition, the annual variation of the water level of the Paraguay River in the study region is approximately $1.50 \mathrm{~m}$, which is the smallest amplitude recorded for the entire Paraguay river (Oliveira et al., 2013). This indicates that the region is very flat and that water from the river channel overflows, laterally flooding large plains (Silva et al., 2007). Due to the small amplitude and flat feature of the region (ICMBio, 2017), the water level above most of the station's soil is approximately $1 \mathrm{~m}$ during the peak of the annual flood, a fact that makes it possible for jaguars to move within the flooded area, without the need to constantly swim in their ranges. These movements within the water also suggest a facility for catching aquatic prey. Jaguars moving during the flooding period in flooded areas of the TES and surroundings have already been observed by managers and researchers, as well as through photographic trap images installed in the TES area (D.L.Z., Kantek, pers. comm., September 2018).

It is concluded that the jaguars continued to use the flooded areas of the TES during the flooding period of the Paraguay River. In addition, individuals F3 and M1, although not resident, remained in flooded areas, evidencing the suitability of this population for this type of environment. The data obtained in this study are complementary to the positive association between jaguars and water bodies detected by several researchers (Crawshaw-Jr. \& Quigley, 1991; Cullen-Jr. et al., 2013; De Angelo et al., 2011; Morato et al., 2018a). In addition, the animals in these localities are installed in one of the wettest regions of the Pantanal (Padovani, 2010) and apparently are already habituated to this situation, which makes these populations differentiated in relation to the other populations of jaguars already registered in the scientific literature.

Finally, from an environmental conservation standpoint, the range of this protected area is not sufficient to effectively protect these jaguar populations, since the grouped home ranges of the resident animals studied are 3.5(wet)/2.5(dry) times larger than the area of the TES (Fig. 2). In another study conducted at the TES, Kantek \& Onuma (2013) also identified the need of increasing the size of the station. The fact that PAs often fail to provide adequate area to support viable populations of wide-ranging species, such as large carnivores, is not 
a new finding and has been documented extensively in the scientific literature (Baeza \& Estades, 2010; Johnson et al., 2006; Mulongoy \& Chape, 2004; Simonetti \& Mella, 1997; Newmark, 1985). In addition, PA size and extinction risk in carnivores is highly correlated (Woodroffe \& Ginsberg, 1998). However, small PAs for large carnivore conservation can be enhanced by improving the quality of the surrounding landscape (Baeza \& Estades, 2010). The surroundings of the TES have low human impact, since there is a private reserve contiguous in the northeast and a flooded region in the southwest where there is no productive human activity, such as crop cultivation, livestock production and aquaculture (ICMBio, 2017). In addition, fishing in the southwest is not allowed, making difficult the access to this area. Furthermore, there is no deforestation between 1990 and 2017 in the region (Projeto MapBiomas, 2020). In this way, our study showed that the landscape context of a protected area may have a significant effect on the persistence of a large carnivore like a jaguar. Even though this population of jaguars is apparently in good conservation status, the expansion or creation of new protected areas is necessary to ensure more efficiency in protecting this jaguar population because environmental changes may occur as a result of future human actions in the private areas surrounding TES. Future efforts to create new areas for conservation should focus mainly on the regions of occurrence of jaguars detected in this study that are not yet legally protected. In addition, the region between the TES and the Pantanal Matogrossense National Park is still very well conserved (Silveira et al., 2014), is connected by the Paraguay River and the land cover is similar to the coverage obtained for the jaguars from TES (Projeto MapBiomas, 2020). So that the region between these two PAs must also be considered to become protected in the future.

\section{AUTHORS' CONTRIBUTIONS}

Morato, R.G., Miyazaki, S.S. and Kantek, D.L.Z. designed the study. Morato, R.G., Miyazaki, S.S., Kantek, D.L.Z., Pereira, T.D.C and Araujo, G.R. did the field activities. Cardoso, H.M and Kantek, D.L.Z. wrote the paper with input from all authors.

\section{ACKNOWLEDGMENTS}

We thank to the Conselho Nacional de Desenvolvimento Científico e Tecnológico (CNPq), Instituto Chico Mendes de Conservação da Biodiversidade (ICMBio), Cat Heaven Endangered Species-Project Survival and Dallas World Aquarium for funding this research. This research is part of the Long-Term Ecological Research Project (PELD) - Ecological Dynamics in the Upper Paraguay River Floodplain (DARP). The authors gratefully thank to the referee for the constructive comments and recommendations which definitely help to improve the quality of the paper.

\section{REFERENCES}

Alho, C.J.R. 2008. Biodiversity of the Pantanal: response to seasonal flooding regime ant to environmental degradation. Brazilian Journal of Biology, 68(4 Suppl.): 957-966.

Assine, M.L. \& Silva, A. 2009. Contrasting fluvial styles of the Paraguay River in the northwestern border of the Pantanal wetland, Brazil. Geomorphology, Amsterdam, 113(3-4): 189-199.

Baeza, A. \& Estades, C.F. 2010. Effect of the landscape context on the density and persistence of a predator population in a protected area subject to environmental variability. Biological Conservation, 143: 94-101.

Balme, G.A.; Hunter, L.T.B. \& Slotow, R. 2009. Evaluating methods for counting cryptic carnivores. Journal of Wildlife Management, 73(3): 433-441.

Baskett, M.L.; Micheli, F. \& Levin, S.A. 2007. Designing marine reserves for interacting species: insights from theory. Biological Conservation, 137(2): 163-179.

Brown, D.E. \& Lopez-Gonzales, C.A. 2001. Borderland jaguars: Tigres de la Frontera. Salt Lake City, University of Utah Press. 170p.

Calabrese, J.M.; Fleming, C.H. \& Gurarie, E. 2016. Ctmm: An R package for analyzing animal relocation data as a continuous-time stochastic process. Methods in Ecology and Evolution, 7: 1124-1132.

Cavalcanti, S.M.C. \& Gese, E.M. 2009. Spatial ecology and social interactions of Jaguars (Panthera Onca) in the Southern Pantanal, Brasil. Journal of Mammalogy, 90(4): 935-945.

Cavalcanti, S.M.C.; Azevedo, F.C.C.; Tomás, W.M.; Boulhosa, R.L.P. \& Crawshaw-Jr., P.G. 2012. The status of the jaguar in the Pantanal. Cat News, 7: 29-34.

Crawshaw-Jr., P.G. \& Quigley, H.B. 1991. Jaguar spacing, activity and habitat use in a seasonally flooded environment in Brazil. Journal of Zoology, London, 223(3): 357-370.

Cullen-Jr., L.; Sana, D.A.; Lima, F.; Abreu, K.C. \& Uezu, A. 2013. Selection of habitat by the jaguar, Panthera onca (Carnivora: Felidae) in the upper Paraná River, Brasil. Zoologia, Curitiba, 30(4): 379-387.

De Angelo, C.; Paviolo, A. \& Di Bitetti, M. 2011. Differential impact of landscape transformation on pumas (Puma concolor) and jaguars (Panthera onca) in the upper Parana Atlantic Forest. Diversity and Distributions, 17(3): 422-436.

Dingle, H. \& Drake, V.A. 2007. What is migration? BioScience, 57: 113-121.

Emmons, L.H. 1987. Comparative feeding ecology of felids in a Neotropical rainforest. Behavioral Ecology and Sociobiology, 20: 271-283.

Frota, A.V.B. da; Ikeda-Castrillon, S.K.; Kantek, D.L.Z. \& Silva, C.J. da. 2017. Macrohabitats da Estação Ecológica de Taiamã, no contexto da Área Úmida Pantanal mato-grossense, Brasil. Boletim do Museu Paraense Emílio Goeldi, Ciências Naturais, 12(2): 239-254.

Frota, A.V.B.; Vitorino, B.D.; da Silva, C.J.; Ikeda-Castrillon, S.K. \& Nunes, J.R.S. 2020. Birds of the Ramsar site Estação Ecológica de Taiamã and buffer zone, Pantanal wetlands, Brazil. Check List, 16: 401-422.

Gour, D.G.; Bhagavatula, J.; Bhavanishankar, M.; Reddy, P.A.; Gupta, J.A.; Sarkar, M.S.; Hussain, S.M.; Harika, S. \& Gulia, R. 2013. Philopatry and dispersal patterns in Tiger (Panthera tigris). PLoS ONE, 8(7): e66956.

Harris, M.B.; Tomas, W.M.; Mourão, G.; Silva, C.J. da; Guimarães, E.; Sonoda, F. \& Fachim, E. 2005. Desafios para proteger o Pantanal brasileiro: ameaças e iniciativas em conservação. Megadiversidade, 1: 156-164.

Howard, W.E. 1960. Innate and environmental dispersal of individual vertebrates. American Midland Naturalist, 63: 152-161.

Inskip, C. \& Zimmerman, A. 2009. Human-felid conflict: a review of patterns and priorities worldwide. Oryx, 43: 18-34.

Instituto Chico Mendes de Conservação da Biodiversidade (ICMBio). 2017. Plano de Manejo da Estação Ecológica de Taiamã. Instituto Chico Mendes de Conservação da Biodiversidade, Brasília, Brasil. Available at: http:// 
www.icmbio.gov.br/portal/images/stories/plano-de-manejo/plano de manejo esec taiama vs 070617.pdf. Access in: 20/01/2020.

Instituto Chico Mendes de Conservação da Biodiversidade (ICMBio). 2018. Livro Vermelho da Fauna Brasileira Ameaçada de Extinção: Volume II Mamiferos. Available at: https://www.icmbio.gov.br/portal/images/ stories/comunicacao/publicacoes/publicacoes-diversas/livro vermelho 2018 vol2.pdf. Access in: 22/10/2019.

Johnson, A.; Vongkhamheng, C.; Hedemark, M. \& Saithongdam, T. 2006. Effects of human? carnivore conflict on tiger (Panthera tigris) and prey populations in Lao PDR. Animal Conservation, 9(4): 421-430.

Junk, W.J. \& Cunha, C.N.D. 2005. Pantanal: a large South American wetland at a crossroads. Ecological Engineering, 24: 391-401.

Junk, W.J. \& Silva, C.J. da. 1999. 0 conceito do pulso de inundação e suas implicações para o Pantanal de Mato Grosso. In: Simpósio sobre Recursos Naturais e Sócio-econômicos do Pantanal, $2^{\circ}$. Anais. Corumbá, EMBRAPA - CPAP. p. 17-28.

Kantek, D.L.Z. \& Onuma, S.S.M. 2013. Jaguar conservation in the region of Taiamã ecological station, northern Pantanal, Brazil. Publicatio UEPG. Ciências Biológicas e da Saúde, 19: 69-74. Available at: https://revistas2. uepg.br//index.php/biologica/article/view/5116.

Morato, R.G.; Beisiegel, B.M.; Ramalho, E.E.; Campos, C.B. De \& Boulhosa, R.L.P. 2013. Avaliação do risco de extinção da Onça-Pintada Panthera onca (Linnaeus, 1758) no Brasil. Biodiversidade Brasileira, 3(1): 122-132.

Morato, R.G.; Connette, G.M.; Stabach, J.A.; Paula, R.C.; Ferraz, K.; Kantek, D.L.Z.; Miyazaki, S.S.; Pereira, T.D.C.; Silva, L.C.; Paviolo, A.; Angelo, C.; Bitetti, M.; Cruz, P.; Lima, F.; Cullen-Jr., L.; Sana, D.A.; Emiliano, E.R.; Carvalho, M.M.; Da Silva, M.X.; Moraes, M.F.D.; Voglioti, A.; May-Jr., J.A.; Haberfeld, M.; Rampin, L.; Sartorello, L.; Araujo, G.R.; Wittemyer, G.; Ribeiro, M.C. \& Leimgruber, P. 2018a. Resource selection in an apex predator and variation in response to local landscape characteristics. Biological Conservation, 228: 233-240.

Morato, R.G.;Thompson, J.J.; Paviolo, A.; De La Torre, J.A.; Lima, F.; Mcbride-Jr., R.T.; Paula, R.C.; Cullen-Jr., L.; Silveira, L.; Kantek, D.L.Z.; Ramalho, E.E.; Maranhão, L.; Haberfeld, M.; Sana, D.A.; Medellin, R.A.; Carrillo, E.; Montalvo, V.; Monroy-Vilchis, 0.; Cruz, P.; Jácomo, A.T.; Torres, N.M.; Alves, G.B.; Cassaigne, I.; Thompson, R.; Saenz-Bolanos, C.; Cruz, J.C.; Alfaro, L.D.; Hagnauer, I.; Da Silva, M.X.; Vogliotti, A.; Moraes, M.F.D.; Miyazaki, S.S.; Pereira, T.D.C.; Araujo, G.R.; Da Silva, L.C.; Leuzinger, L.; Carvalho, M.M.; Rampim, L.; Sartorello, L.; Quigley, H.; Tortato, F.; Hoogesteijn, R.; Crawshaw-Jr., P.G.; Devlin, A.L.; May-Jr., J.A.; De Azevedo, F.C.C.; Concone, H.V.B.; Quiroga, V.A.; Costa, S.A.; Arrabal, J.P.; Vanderhoeven, E.; Di Blanco, Y.E.; Lopes, A.M.C.; Widmer, C.E. \& Ribeiro, M.C. 2018b. Jaguar Movement Database: a GPS-based movement dataset of an apex predator in the Neotropics. Ecology, 99(7): 1691-1691.

Morato, R.G.; Stabach, J.A.; Fleming, C.H.; Calabrese, J.M.; Paula, R.C.; Ferraz, K.; Kantek, D.L.Z.; Miyazaki, S.S.M.; Pereira, T.D.C.; Araujo, G.; Paviolo, A.; Angelo, C.; Bitetti, M.; Cruz, P.; Lima, F.; Cullen-Jr., L.; Sana, D.A.; Emiliano, E.R.; Carvalho, M.M.; Soares, F.H.S.; Zimbres, B.; Silva, M.X.; Voglioti, A.; May-Jr., J.A.; Haberfeld, M.; Rampin, L.; Sartorello, L.; Ribeiro, M.C. \& Leimgruber, P. 2016. Space use and movement of a neotropical top predator: the endangered jaguar. Plos One, 11(12): e0168176.

Morrison, C.D.; Boyce, M.S. \& Nielsen, S.E. 2015. Space-use, movement and dispersal of sub-adult cougars in a geographically isolated population. PeerJ, 3: e1118.

Mulongoy, K.J. \& Chape, S. 2004. Protected areas and biodiversity: an overview of key issues. UNEP-WCMC Biodiversity Series 21. Available at: https://ia800302.us.archive.org/0/items/protectedareasbi04mulo/ protectedareasbi04mulo.pdf. Access in: 20/06/2020.

Muniz, C.C.; Santana, M.N. \& Junior, E.S.0. 2016. Índices morfofisiológicos de Piaractus mesopotamicus (Osteichthyes, Characidae) na Estação
Ecológica de Taiamã e foz do rio Sepotuba, Brasil. Interciência, Recife, 41(10): 674-679.

Newmark, W.D. 1985. Legal and biotic boundaries of western North American national parks: A problem of congruence. Biological Conservation, 33: 197-208.

Nowell, K. \& Jackson, P. 1996. Wild Cats - Status Survey and Conservation Action Plan. Gland, UICN/SSC.

Ogada, M.0.; Woodroffe, R.; Oguge, N.O. \& Frank, L.G. 2003. Limiting depredation by African carnivores: the role of livestock husbandry. Conservation Biology, 17(6): 1521-1530.

Oliveira, M.D. De\& Calheiros, D.F.2000. Flood pulse influence on phytoplankton communities of the south Pantanal floodplain, Brazil. Hydrobiology, The Hague, 427(1-3): 102-112.

Oliveira, R.A. de; Silva, J.S. da; Calmant, S. \& Seyler, F. 2013. Caracterização do regime hidrológico do rio Paraguai utilizando dados da missão altimétrica ENVISAT. In: Simpósio Brasileiro de Recursos Hídricos, 20. Anais. Bento Gonçalves (RS), Associação Brasileira de Recursos Hidricos. $8 \mathrm{p}$.

Padovani, C.R. 2010. Dinâmica espaço-temporal das inundações do Pantanal. (Doctoral Thesis). Universidade de São Paulo, Piracicaba.

Projeto MapBiomas. 2020. Coleção 4.1 da Série Anual de Mapas de Cobertura e Uso de Solo do Brasil. Available at: http://mapbiomas.org. Access in: $12 / 06 / 2020$.

Quigley, H.; Foster, R.; Petracca, L.; Payan, E.; Salom, R. \& Harmsen, B. 2017. Panthera onca (errata version published in 2018). The IUCN Red List of Threatened Species, 2017: e.T15953A123791436.

Quigley, H.B. \& Crawshaw-Jr., P.G.A. 1992 conservation plan for the jaguar Panthera onca in the Pantanal region of Brazil. Biological Conservation, 61: 149-167.

Sanderson, E.W.; Redford, K.H.; Chetkiewicz, C.; Medellin, R.A.; Rabinowitz, A.R.; Robinson, J.G. \& Taber, A.B. 2002. Planning to Save a Species: the Jaguar as a Model. Conservation Biology, 16: 58-72.

Santana, M.; Ferreira; Souza, C.A. de \& Oliveira-Jr., E.S. 2013. Análise de séries temporais de vazão e precipitação na bacia do rio Paraguai. Revista GeoPantanal, Corumba, 8(14): 67-89.

Schaller, G.B. \& Crawshaw-Jr., P.G. 1980. Movement Patterns of Jaguar. Biotropica, Washington, 12: 161-168.

Seymour, K.L. 1989. Panthera onca. Mammalian species, 340: 1-9.

Silva, A.; Assine, M.L.; Zani, H.; Filho, E.E. de S. \& Araújo, B.C. 2007. Compartimentação Geomorfológica do rio Paraguai na borda norte do Pantanal Mato-Grossense, região de Cáceres, MT. Revista Brasileira de Cartografia, 59: 73-81.

Silveira, L.; Sollman, R.; Jácomo, A.T.A.; Diniz Filho, J.A.F. \& Tôrres, N.M. 2014. The Potencial for large-scale wildlife corridors between protected areas in Brazil using the jaguar as a model species. Landscape Ecology, 29: 1213-1223.

Silver, S.C.; Ostro, L.E.T.; Marsh, L.K.; Maffei, L.; Noss, A.J.; Kelly, M.J.; Wallace, R.B.; Gomez, H. \& Crespo, G.A. 2004. The use of camera trap for estimating jaguar (Panthera onca) abundance and density using capture/recapture analysis. Oryx, Oxford, 38: 148-154.

Simonetti, J.A. \& Mella, J.E. 1997. Park size and the conservation of Chilean mammals. Revista Chilena de Historia Natural, 70: 213-220.

Terborgh, J. 1990. The role of felid predators in Neotropical Forests. Vida Silvestre Neotropical, 2: 3-5.

Tomas, W.M.; Roque, F. de 0.; Morato, R.G.; Médici, P.E.; Chiaravalloti, R.M.; Tortato, F.R.; Penha, J.M.F.; Izzo, T.J.; Garcia, L.C.; Lourival, R.F.F.; Girard, P.; Albuquerque, N.R.; Almeida-Gomes, M.; Andrade, M.H. da S.; Araújo, F.A.S.; Araújo, A.C.; Arruda, E.C. de; Assunção, V.A.; Battirola, L.D.; Benites, M.; Bolzan, F.P.; Boock, J.C.; Bortolotto, I.M.; Brasil, M. da S.; Camilo, A.R.; Campos, Z.M. da S.; Carniello, M.A.; Catella, A.C.; Cheida, C.C.; Crawshaw-Jr., P.G.; Crispim, S.M.A.; Damasceno-Jr., G.A.; Desbiez, A.L.J.; 
Dias, F.A.; Eaton, D.P.; Faggioni, G.P.; Farinaccio, M.A.; Fernandes, J.F.A.; Ferreira, V.L.; Fischer, E.A.; Fragoso, C.E.; Freitas, G.0.; Galvani, F.; Garcia, A.S.; Garcia, C.M.; Graciolli, G.; Guariento, R.D.; Guedes, N.M.R.; Guerra, A.; Herrera, H.M.; Hoogesteijn, R.; Ikeda, S.C.; Juliano, R.S.; Kantek, D.L.Z.; Keuroghlian, A.; Lacerda, A.C.R.; Lacerda, A.L.R.; Landeiro, V.L.; Laps, R.R.; Layme, V.; Leimgruber, P.; Rocha, F.L.; Mamede, S.; Marques, D.K.S.; Marques, M.I.; Mateus, L.A.F; Moraes R.N.; Moreira, T.A.; Mourao, G. de M.; Nicola, R.D.; Nogueira, D.G.; Nunes, A.P.; Cunha, C.N. da; Oliveira, M.D. de; Oliveira, M.R.; Paggi, G.M.; Pellegrin, A.0.; Pereira, G.M.F.; Peres, I.A.H.F.S.; Pinho, J.B.; Pott, A.; Provete, D.B.; Reis, V.D.A. dos; Reis, L.K. dos; Renaud, P.C.; Ribeiro, D.B.; Rossetto, O.C.; Sabino, J.; Rumiz, D.; Salis, S.M. de; Santana, D.J.; Santos, S.A.; Sartori, Â.L.; Sato, M.; Schuchmann,
K-L.; Scremin-Dias, E.; Seixas, G.H.F.; Severo-Neto, F.; Sigrist, M.R.; Silva, A.; Silva, C.J.; Siqueira, A.L.; Soriano, B.M.A.; Sousa, L.M.; Souza, F.L.; Strussmann, C.; Sugai, L.S.M.; Tocantins, N.; Urbanetz, C.; Valente-Neto, F.; Viana, D.P.; Yanosky, A. \& Junk, W.J. 2019. Sustainability Agenda for the Pantanal Wetland: Perspectives on a Collaborative Interface for Science, Policy, and Decision-Making. Tropical Conservation Science, 12: 1-30.

Wantzen, K.M.; Drago, E. \& da Silva, C.J. 2005. Aquatic habitats of the Upper Paraguay River-Floodplain-System and parts of the Pantanal (Brazil). Ecohydrology \& Hydrobiology, 21: 1-15.

Woodroffe, R. \& Ginsberg, J.R. 1998. Edge effects and the extinction of populations inside protected areas. Science, Washington, 280(5372): 2126-2128. 